Check for updates

Cite this: RSC Adv., 2017, 7, 36081

\title{
Ambient light induced antibacterial action of curcumin/graphene nanomesh hybrids
}

\author{
Z. M. Marković, (D) *a D. P. Kepić, ${ }^{b}$ D. M. Matijašević, ${ }^{c}$ V. B. Pavlović, ${ }^{c}$ S. P. Jovanović, ${ }^{b}$ \\ N. K. Stanković, ${ }^{e}$ D. D. Milivojević, ${ }^{b}$ Z. Spitalsky, ${ }^{a}$ I. D. Holclajtner-Antunović, ${ }^{d}$ \\ D. V. Bajuk-Bogdanović, ${ }^{d}$ M. P. Nikšićc and B. M. Todorović Marković (D)*b
}

\begin{abstract}
Curcumin and its derivates are well-known for their different biological activities including antibacterial. On the other hand there are controversial reports concerning the antibacterial potential of graphene and, in particular, graphene oxide. In this study we have reported for the first time the antibacterial activity of curcumin/graphene nanomesh hybrids under ambient light conditions. The graphene nanomesh was synthesized by electrochemical exfoliation of highly oriented pyrolytic graphite in $1 \mathrm{M}$ solution of ammonium persulfate and further functionalized by curcumin. Identical values of minimum inhibitory concentration ( $1 \mathrm{mg} \mathrm{mL} \mathrm{mL}^{-1}$ ) were determined for pure curcumin and curcumin/graphene nanomesh hybrids toward Staphylococcus aureus. All tested samples had more pronounced antibacterial activity against Gram positive bacteria, Staphylococcus aureus compared to Escherichia coli as a representative of Gram negative strains. The poor antibacterial potential of exfoliated graphene improves significantly by the functionalization with curcumin, which allows for its usage as a antibacterial coating.
\end{abstract}

Received 4th May 2017

Accepted 14th July 2017

DOI: 10.1039/c7ra05027e

rsc.li/rsc-advances assumed that the antibacterial properties of graphene are to be caused by chemical and physical interactions upon the direct contact of graphene sheets with bacteria in which the bacterial cell membrane seems to be the main target of this activity. ${ }^{\mathbf{1 4}}$ Upon interactions among bacteria strains and graphene based materials, different types of bacteria membrane damages can be identified: ribonucleic acid (RNA) leakage, release of intracellular components and variations in the transmembrane capacity, lipid peroxidation initiated by the oxidative ability of graphene oxide. Different parameters of graphene based materials affect the bacteria membrane damage: lateral dimension of graphene sheets, concentration, surface area, surface roughness, hydrophilicity, dispersibility and functionalization.

A variety of mechanisms for the antibacterial activity of graphene materials have been proposed, including membrane stress, oxidative stress and electron transfer. ${ }^{15}$ Membrane stress: nanosheets of graphene can cause physical damage to bacterial membranes. Oxidative stress: Reactive Oxygen Species (ROS) produced by graphene are harmful to lipids and proteins of bacteria. After the deactivation of lipids and proteins, bacteria can no longer proliferate. Electron transfer: antibacterial activity may be produced via the transfer of electrons from the microbial membrane to the graphene surface rather than stemming from ROS mediated damage. ${ }^{16-18}$

Curcumin is a component of the Indian spice turmeric (Curcumin longa L.) and extracted from the rhizomes of it. Commercially available curcumin is a mixture of three curcu-

minoids, namely, curcumin, demethoxy- and bisdemethoxy-

\footnotetext{
"Polymer Institute, Slovak Academy of Sciences, Dubravska cesta 9, 84541 Bratislava,

Belgrade, Serbia. E-mail: biljatod@vin.bg.ac.rs; Tel: +381 113408582

'Faculty of Agriculture, University of Belgrade, Nemanjina 6, 11080 Belgrade-Zemun, Serbia

${ }^{d}$ Faculty of Physical Chemistry, University of Belgrade, Studentski trg 12-16, 11158 Belgrade, Serbia

${ }^{e}$ The School of Electrical Engineering, University of Belgrade, Bulevar kralja Aleksandra 73, 11000 Belgrade, Serbia
} 
curcumin, the latter two amounting to nearly $30 \%$ in samples labeled "pure". ${ }^{19}$ It shows a remarkable range of pharmacological activity, including antioxidant, anti-inflammatory and anticancer activity as well antibacterial. ${ }^{20-27}$ Paunović et al. found that photoexcited nanocurcumin displayed a significant cytotoxicity depending both on the irradiation time and nanocurcumin concentration. ${ }^{26}$ In the absence of blue light irradiation nanocurcumin displayed very small cytotoxicity. Recently some studies showed that curcumin suppresses adherence of Streptococcus mutants to human tooth surfaces and extracellular matrix protein..$^{28}$ Furthermore, in this study it is emphasized that curcumin possesses a synergetic effect with important antibiotics against Staphylococcus aureus (S. aureus). ${ }^{29-31}$ Tyagi et al. have demonstrated in their study that membrane damage is a key mechanism of curcumin mediated killing of $S$. aureus and Escherichia coli (E. coli), i.e. curcumin caused membrane permeabilization of both bacteria strains despite their significantly different cell wall properties. ${ }^{27}$ However, very few studies have tackled the mechanism of antibacterial activity of curcumin which seems to differ depending on the strain being studied.

Recently it is reported that the synthesis of colloidal graphene based nanocarriers with high drug loading capacities and with targeting ligands at the outer space is a challenging issue. ${ }^{32}$ Muthoosamy et al. reported that curcumin-paclitaxel onto polymer-functionalized reduced graphene oxide is highly potent for synergistic anticancer treatment. ${ }^{33}$ Hatamie et al. reported that curcumin was used for green reduction and functionalization of chemically exfoliated graphene oxide sheets. It was found that cytotoxicity of curcumin/reduced graphene oxide sheets is concentration dependent. At concentrations higher than $100 \mu \mathrm{g} \mathrm{mL} \mathrm{m}^{-1}$ some slight cytotoxic effects are observed. In addition, the interaction of the reduced graphene oxide and cells resulted in apoptosis as well as morphological transformation of the cells. ${ }^{34}$ Mitra et al. showed recently that curcumin loaded collagen functionalized nano graphene oxide promote cell adherence and proliferation. The antimicrobial study reveals the curcumin loaded collagen functionalized nano graphene oxide scaffold has appreciable antibacterial activity. These authors claim as well that in vitro cell line study do not show toxicity of the collagen functionalized nano graphene oxide against NIH 3T3 fibroblast cell line. ${ }^{35}$ Choi et al. reported a facile and environmentally friendly approach for the synthesis of reduced graphene oxide using uric acid. These authors showed that graphene oxide and uric acid-reduced graphene oxide induced a dose-dependent decrease in cell viability and induced cytotoxicity in human ovarian cancer cells. The results from their study suggest that uric acid-reduced graphene oxide could cause apoptosis in mammalian cells and the toxicity of uric acid-reduced graphene oxide is significantly higher than graphene oxide. ${ }^{36}$

Graphene nanomesh is a structural derivate of graphene and is formed by removing large number of atoms from the graphitic plane to produce holes distributed on and through the atomic thickness of the graphene sheets. ${ }^{37}$ Due to its changed electronic properties induced by quantum confinement of the remaining graphitic structure there is a great possibility for electronic application of this material. ${ }^{38}$ Besides, a large number of hole-edge functional groups provides many more active sites and can increase the sensitivity or response toward targeted chemical or biological species. ${ }^{39}$

In this paper we have studied antibacterial activity of curcumin/graphene nanomesh hybrids in order to improve antibacterial properties of exfoliated graphene investigated previously. ${ }^{40}$ Graphene is exfoliated from highly oriented pyrolytic graphite (HOPG) through electrochemical exfoliation process with ammonium persulfate as an electrolyte. Colloids of curcumin and curcumin/graphene nanomesh hybrids were obtained by solvent exchange method. Structural and antibacterial properties of curcumin and curcumin/graphene nanomesh hybrids are investigated by applying atomic force microscopy, transmission electron microscopy, scanning electron microscopy, Fourier transform infrared spectroscopy, Raman spectroscopy, zeta potential measurements, electron paramagnetic resonance measurements and antibacterial tests.

\section{Experimental section}

\subsection{Exfoliation of graphene}

Electrochemical exfoliation of HOPG was performed in a twoelectrode system using graphite rod as the counter electrode and a HOPG as the working electrode as reported previously. ${ }^{\mathbf{4 1}}$ Electrolyte solution was prepared by dissolving $\left(\mathrm{NH}_{4}\right)_{2} \mathrm{~S}_{2} \mathrm{O}_{8}$ in water to obtain concentration of $1 \mathrm{M}$. Direct current (DC) voltage of $+12 \mathrm{~V}$ was applied to the HOPG electrode and the voltage was kept constant until the exfoliation process completed (indicated by the total consumption of the HOPG electrode). Exfoliated product was collected by vacuum filtration and washed with copious amount of water to remove any residual salt. After washing the material was collected and dried in air. Further in the text this material will be designated as the EHOPG.

\subsection{Extraction of curcumin}

An amount of approximately $50 \mathrm{~g}$ of dry turmeric powder (Curcuma longa L.) was placed in the Soxhlet apparatus. Ethanol (96\% purity, Fisher Chemical) was used as an extraction solvent. The extraction was kept running until the yellow color of the extractions faded. Concentration of curcumin in solution was determined by gravimetry.

\subsection{Preparation of curcumin, EHOPG, and curcumin- EHOPG colloids}

Ethanol solution of curcumin $(10 \mathrm{~mL})$ and water based EHOPG colloid $(40 \mathrm{~mL})$ were mixed and sonicated. The more volatile ethanol was subsequently removed from the solution using a rotary evaporator at $50{ }^{\circ} \mathrm{C}$. Milli-Q water was added four times more and evaporated to the initial volume. Final solution was diluted in order to obtain concentration of $2 \mathrm{mg} \mathrm{mL}^{-1}$. Further in the text this material will be designated as the curcuminEHOPG.

For the comparison, curcumin colloid was prepared in the same way, with the final concentration of curcumin of $4 \mathrm{mg}$ 
$\mathrm{mL}^{-1}$. EHOPG colloid was prepared by sonication of EHOPG powder in water and centrifugation. ${ }^{41}$ All colloids possess longterm stability. The EHOPG and curcumin-EHOPG samples are dialyzed through Sterlitech glass fiber extraction thimbles with pore size of $1 \mu \mathrm{m}$ for 4 days.

\subsection{Characterization of curcumin, EHOPG and curcumin- EHOPG colloids}

Microstructure and morphology of curcumin, EHOPG and curcumin-EHOPG particles were recorded by transmission electron microscopy (TEM-JEOL JEM-1400, accelerating voltage $120 \mathrm{kV}$ ) and atomic force microscope (AFM-Bruker, Germany) equipped with ScanAsyst probes. All samples for TEM are deposited on lacey carbon copper grid (200 mesh). For AFM measurements samples for were deposited by spin-coating on freshly cleaved mica and dried in vacuum at $200{ }^{\circ} \mathrm{C}$.

All AFM images were obtained at $1 \mathrm{~Hz}$, with a $512 \times 512$ image resolution over different square areas. The imaging mode used in our work was PeakForce QNM. Gwyddion software was used to measure lateral and height dimensions of the curcumin, EHOPG and curcumin-EHOPG samples as well as for determination of surface roughness-root-mean square roughness (rms). ${ }^{42}$

Zeta potential ( $\zeta$-potential) of the curcumin, EHOPG and curcumin-EHOPG particles were assessed by DLS using Zetasizer Nano-ZS (Malvern Instruments, UK) equipped with a $4 \mathrm{~mW}$ helium/neon laser $(\lambda=633 \mathrm{~nm})$ and thermo-electric temperature controller, with the following parameters set for graphene colloidal particles: refractive index $=2.67$, absorption $=0.01$, and viscosity $=0.89 \mathrm{cP}$. All measurements were performed at $25{ }^{\circ} \mathrm{C}$. Value of zeta potential was averaged from five measurements.

UV-vis absorption spectra of sample solutions were measured at $20{ }^{\circ} \mathrm{C}$ using a spectrophotometer Shimadzu UVvisible UV-2600 (Shimadzu Corporation, Tokyo, Japan) in the range of $200-800 \mathrm{~nm}$ and with $1 \mathrm{~nm}$ step. All samples were prepared with Milli-Q water in concentration of $0.5 \mathrm{mg} \mathrm{mL}^{-1}$.

The Fourier transform infrared spectroscopy (FTIR) spectra of the curcumin, EHOPG and curcumin-EHOPG KBr pellets were measured at room temperature in the spectral range from 400 to $4000 \mathrm{~cm}^{-1}$ on an Avatar 370, Thermo Nicolet spectrometer. $\mathrm{KBr}$ pellets were made by mixing $150 \mathrm{mg} \mathrm{KBr}$ powder and $1 \mathrm{mg}$ curcumin, EHOPG and curcumin-EHOPG powder, respectively. The spectral resolution was $4 \mathrm{~cm}^{-1}$.

Raman spectra of the curcumin, EHOPG and curcuminEHOPG samples were obtained by DXR Raman microscope (Thermo Scientific) using $532 \mathrm{~nm}$ excitation line with power of 5 $\mathrm{mW}$. The spectral resolution was $1 \mathrm{~cm}^{-1}$. Acquisition time was $10 \times 10 \mathrm{~s}$. Raman spectra were recorded at room temperature. All samples are deposited on silicon substrates.

Electron Paramagnetic Resonance (EPR) analyses were performed at room temperature using a EPR Spectrometer Miniscope 300, Magnettech, Berlin, Germany, operating at a nominal frequency of $9.5 \mathrm{GHz}$. The microwave power was $1 \mathrm{~mW}$ (microwave attenuation of $20 \mathrm{~dB}$ ), with a modulation amplitude of $0.2 \mathrm{mT}$. UV irradiation was performed within the EPR resonator, through irradiation window, using Hamamatsu LC8 spot light source, typeL9566-01, radiant wavelength range (300$450 \mathrm{~nm})$.

The formation of singlet oxygen $\left({ }^{1} \mathrm{O}_{2}\right)$ was followed by specific reaction between ${ }^{1} \mathrm{O}_{2}$ and 2,2,6,6-tetramethylpiperidine (TEMP) in which a stable radical adduct, TEMP- ${ }^{1} \mathrm{O}_{2}$ (or TEMPO) was formed. Samples, in concentration of $0.2 \mathrm{wt} \%$, were mixed with TEMP (at a final concentration of $30 \mathrm{mM}$ ). Prepared mixtures were air-saturated before EPR measurements. All three mixtures were measured before and during light exposure. These mixtures were exposed to UV-vis light $(\lambda>300 \mathrm{~nm})$ for 10 minutes.

The ability of dispersions to produce hydroxyl $\left(\mathrm{HO}^{\circ}\right)$ and superoxide $\left(\mathrm{O}_{2}^{--}\right)$radicals was studied using 5,5-dimethyl-1pyrroline- $N$-oxide (DMPO) as a spin trap for both of these radical species. For EPR measurements, we prepared mixtures of DMPO, in final concentration of $100 \mathrm{mM}$ and sample, where concentration of material was $0.5 \mathrm{mg} \mathrm{mL}{ }^{-1}$. As a control, we used DMPO solution and as well as Fenton reaction with DMPO. Fenton reaction was prepared by mixing of $30 \mu \mathrm{L}$ of $\mathrm{FeCl}_{2}$ (concentration of $1 \mathrm{mM}$ ) and $20 \mu \mathrm{L}$ of $\mathrm{H}_{2} \mathrm{O}_{2}$ (concentration of 10 $\mathrm{mM})$ with DMPO.

\subsection{Bacteria strains and culture conditions}

The antibacterial activities of the curcumin, EHOPG and curcumin-EHOPG were performed against Escherichia coli ATCC 25922 and Staphylococcus aureus ATCC 25923. Selected species of bacteria originate from ATCC (American Type Culture Collection, Rockville, Maryland). The cultivation/assay medium for tested bacteria strains was Müeller Hinton Broth (MHB)/ agar (MHA) (HiMedia Laboratories, India). Concentrations of approximately $10^{5}$ to $10^{6} \mathrm{CFU} \mathrm{mL}^{-1}$ were prepared from overnight broth culture of test strain and used for the antibacterial activity assays.

\subsection{Effect of curcumin, EHOPG and curcumin-EHOPG on cell growth monitored by measuring optical density (OD)}

Curcumin, EHOPG and curcumin-EHOPG stock solutions of $4 \mathrm{mg} \mathrm{mL}{ }^{-1}, 1 \mathrm{mg} \mathrm{mL} L^{-1}$ and $2 \mathrm{mg} \mathrm{mL}^{-1}$, respectively were sterilized by gamma irradiation at a dose of $10 \mathrm{kGy}$ and used to examine the kinetics of bacterial growth using 96-well plates. $\mathrm{pH}$ of prepared colloids were adjusted to value 7 . The wells of the microtiter plates, filled with $100 \mu \mathrm{L}$ of two-fold serially diluted samples in water, were then inoculated with $100 \mu \mathrm{L}$ of the bacterial suspension. Concentrations of curcumin ranged from 0.125 to $2 \mathrm{mg} \mathrm{mL}^{-1}$, for EHOPG from 0.125 to $0.5 \mathrm{mg} \mathrm{mL}^{-1}$ and for curcumin-EHOPG from 0.125 to $1 \mathrm{mg} \mathrm{mL}^{-1}$. Negative controls were wells with growth medium and curcumin, EHOPG or curcumin-EHOPG while MH broth with the tested bacteria served as positive controls. The microplate reader (ELx808, BioTek Instruments, Inc., USA) controlled by Gen5TM software was used to monitor the cell growth by measuring the turbidity $\mathrm{OD}_{630}$ (optical density at $630 \mathrm{~nm}$ ) at $60 \mathrm{~min}$ intervals during $24 \mathrm{~h} . \mathrm{OD}_{630}$ is a method used to determine the amount of light scattered by the bacteria rather than the amount of light absorbed and is proportional to the cell density. ${ }^{43}$ Plate was 
shaken for $10 \mathrm{~s}$ before every reading. The $\mathrm{OD}_{630}$ was corrected for OD of negative control at the same point of measurement.

\subsection{Bacteria growth in the presence of curcumin, EHOPG and curcumin/graphene determined by viable count}

Bacteria growth in the presence of curcumin, EHOPG and curcumin-EHOPG was determined by macrodilution method, according to Klančnik et al. ${ }^{44}$ with slight modification. An aliquot of $S$. aureus inoculum was mixed with the same volume of curcumin, curcumin-EHOPG or EHOPG dilutions to give a final concentration of samples in the range of $0.25-2 \mathrm{mg}$ $\mathrm{mL}^{-1}, 0.25-1 \mathrm{mg} \mathrm{mL}^{-1}$ and $0.5 \mathrm{mg} \mathrm{mL}^{-1}$, respectively. Similarly, the curcumin, curcumin-EHOPG or EHOPG were added in $1 \mathrm{~mL}$ of $E$. coli suspension to give the final concentration of the samples of $2 \mathrm{mg} \mathrm{mL}{ }^{-1}, 1 \mathrm{mg} \mathrm{mL}^{-1}$ and $0.5 \mathrm{mg} \mathrm{mL}^{-1}$, respectively. These concentrations were chosen according to the results of previous assay. Negative controls were wells with growth medium and curcumin, EHOPG or curcumin-EHOPG while $\mathrm{MH}$ broth with the tested bacteria served as positive controls. The concentration of bacteria was determined at regular intervals during $24 \mathrm{~h}$ incubation by serial dilution of the samples and plating out the aliquot $(10-100 \mu \mathrm{L})$ on the surface of MHA. The plates were incubated under aerobic conditions, at $37^{\circ} \mathrm{C}$ for $24 \mathrm{~h}$, and the total number of colonies was counted. The number of the tested bacteria (expressed as $\log _{10} \mathrm{CFU}$ $\mathrm{mL}^{-1}$ ) was calculated by taking into account dilution of the samples and the amount plated out on the MHA. All experiments were performed in triplicates and the mean $\log _{10} \mathrm{CFU}$ $\mathrm{mL}^{-1}$ as well as the standard deviations were calculated.

\subsection{Effect of curcumin, EHOPG and curcumin/graphene on cell growth visualized by SEM}

Visualization of interactions between the curcumin, EHOPG and curcumin-EHOPG and bacterial strains was performed using scanning electron microscopy (SEM-JEOL JSM-6390LV) in vacuum with $10 \mathrm{kV}$ acceleration voltages. Examination of the morphological changes of the bacterial cells was performed according to a slightly optimized version of the procedure described by Tyagi et al. ${ }^{45} \mathrm{~S}$. aureus suspension of approximately $10^{5}$ to $10^{6} \mathrm{CFU} \mathrm{mL}{ }^{-1}$ was treated with $1 \mathrm{mg} \mathrm{mL}^{-1}$ of curcumin, $0.5 \mathrm{mg} \mathrm{mL} \mathrm{m}^{-1}$ of EHOPG and $1 \mathrm{mg} \mathrm{mL}^{-1}$ of curcumin-EHOPG or left untreated as the control. E. coli suspension was treated with $2 \mathrm{mg} \mathrm{mL}{ }^{-1}$ of curcumin, $0.5 \mathrm{mg} \mathrm{mL}^{-1}$ of EHOPG and $1 \mathrm{mg} \mathrm{mL}^{-1}$ of curcumin-EHOPG or left untreated as the control. These suspensions were incubated for an additional $8 \mathrm{~h}$ at $37^{\circ} \mathrm{C}$, harvested by centrifugation $\left(6000 \mathrm{rpm}, 10 \mathrm{~min}\right.$ at $\left.4{ }^{\circ} \mathrm{C}\right)$ and fixed with $2.5 \%$ glutaraldehyde over night at $4{ }^{\circ} \mathrm{C}$. The obtained cell pellets were washed three times with $0.1 \mathrm{M}$ sodium phosphate buffer ( $\mathrm{pH} 7.2)$ and dehydrated with graded ethanol series $25 \%$, $50 \%, 75 \%, 90 \%$ and $2 \times 100 \%, 15 \mathrm{~min}$ each. The dehydrated samples were air dried immediately, followed by smearing on SEM stubs. All prepared samples of bacterial strains (treated with curcumin, EHOPG, curcumin-EHOPG and controls) were gold-covered by a Baltec scd 005 sputter coater accessory and recorded at room temperature. The samples are denoted as the following: E. coli control-ECC, S. aureus control-SAC, treated with curcumin-ECCU, and SACU, treated with EHOPGECEHOPG and SAEHOPG, treated with curcumin-EHOPGECCUEHOPG and SACUEHOPG, respectively. Samples elementary composition was obtained with energy dispersive spectroscopy (EDS, Oxford Aztec X-max). The scanned surface area was $10 \times 10 \mu \mathrm{m}^{2}$.

\subsection{Loss of $260 \mathrm{~nm}$-absorbing material}

The extracellular $260 \mathrm{~nm}$-absorbing material released by the cells was determined using slightly modified method described by Carson $e t$ al. ${ }^{46}$ Bacterial suspensions (pretreatment sample) of approximately $10^{5}$ to $10^{6} \mathrm{CFU} \mathrm{mL} \mathrm{m}^{-1}$ were taken, diluted in a ratio $1: 100$, and filtered through a $0.22 \mu \mathrm{m}$ pore size filter (Sartorius, Germany). The curcumin, EHOPG and curcuminEHOPG were added in $1 \mathrm{~mL}$ of $S$. aureus suspension to reach final concentrations of $1 \mathrm{mg} \mathrm{mL} \mathrm{m}^{-1}, 1 \mathrm{mg} \mathrm{mL}^{-1}$ and $0.5 \mathrm{mg}$ $\mathrm{mL}^{-1}$, respectively. Cells without samples were used as a control. All the samples were incubated at $37{ }^{\circ} \mathrm{C}$, and additional aliquots of control and treated cell suspensions were removed after 4 and $8 \mathrm{~h}$, diluted and filtered as described above. The release of UV-absorbing material was measured using a Shimadzu UV-1800 UV-vis spectrophotometer. The obtained results of the measurements at $260 \mathrm{~nm}$ at each time were expressed as a proportion of the initial $\mathrm{OD}_{260}$ value. $\mathrm{An} \mathrm{OD}_{260}$ is defined as the amount of light at a $260 \mathrm{~nm}$ wavelength which will be absorbed by an oligo if it is resuspended in $1 \mathrm{~mL}$ water and the concentration is read in a $1 \mathrm{~cm}$ quartz cuvette. The assay was carried out in triplicates.

\section{Results}

\subsection{Surface morphology of the EHOPG, curcumin, curcumin-EHOPG}

Surface morphology and microstructure of the curcumin, EHOPG and curcumin-EHOPG particles were studied on AFM and TEM and presented in Fig. 1a-h. Average lateral dimension of the EHOPG is $500 \mathrm{~nm}$ based on calculation of Gwyddion software whereas average height is $1 \mathrm{~nm}$ (inset of Fig. 1a). The obtained value of the EHOPG height is slightly higher than that for typical single layer graphene oxide $(0.8 \mathrm{~nm}){ }^{47}$ It is thicker than the typical thickness of graphene $(\sim 0.36 \mathrm{~nm})$, due to bonding the oxygen-containing functional groups on each side of sheet. ${ }^{47-49}$ But the presence of numerous bonded oxygen functional groups (carbonyl, epoxy and hydroxyl) on the basal plane and the edges of EHOPG sheets contributes significantly to higher height value. TEM micrograph (Fig. 1e) confirms that the EHOPG sample is single layer graphene. There are several pores with average diameters of $15 \mathrm{~nm}$ over the entire surface of the EHOPG sample - Fig. 1a. The pores are uniformly distributed over the entire surface of the EHOPG sheets. Pores are clearly seen on the surface of the EHOPG sheet indicating the formation of porous graphene sheets. This porous single layer structure with a moderate density array of nanoscale holes punched in is defined as graphene nanomesh. It can be made only after exfoliation in $1 \mathrm{M}$ solution of APS. In Fig. 1b, typical curcumin nanoparticle is presented. Its average diameter is 

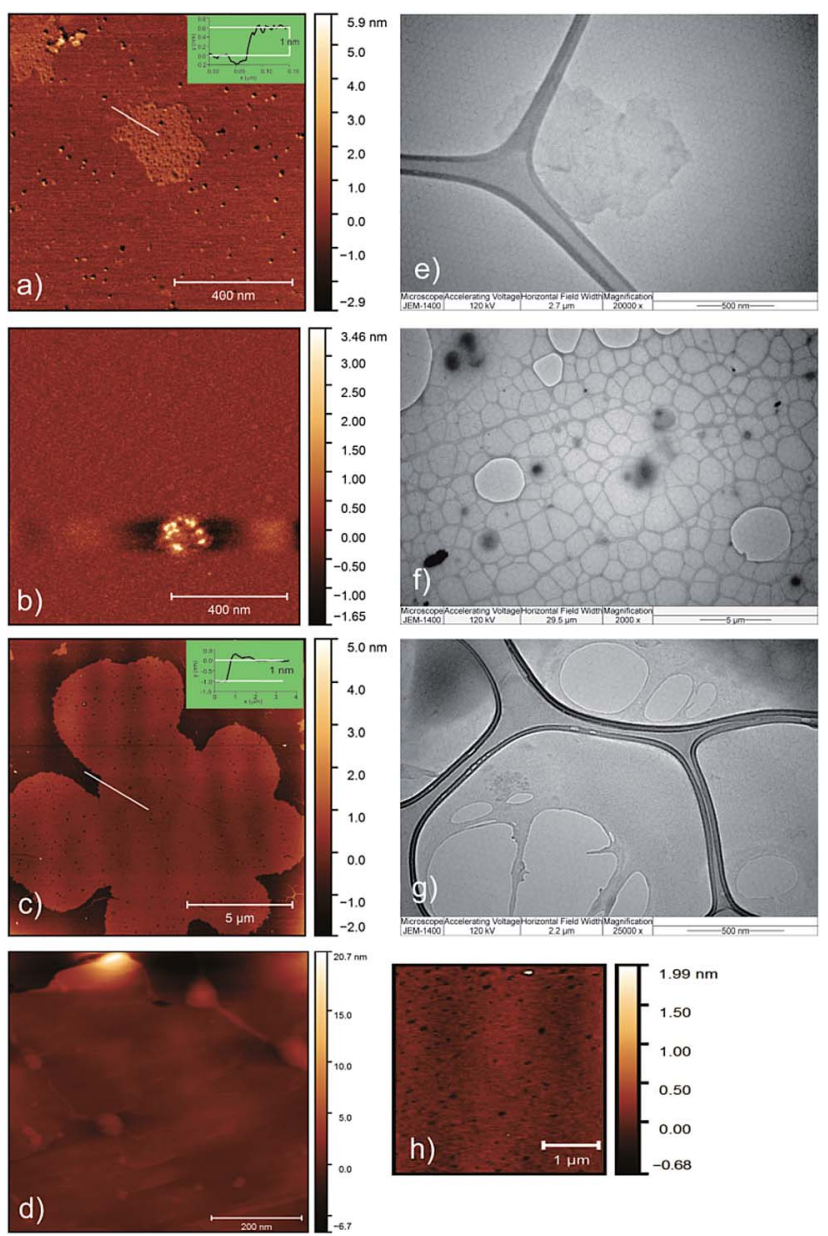

Fig. 1 (a) Top view AFM image and height profile (inset) of the EHOPG sample; (b) top view AFM image of the curcumin sample; (c) top view AFM image and height profile (inset) of the curcumin-EHOPG sample; (d) top view magnified AFM image of the surface of the curcuminEHOPG sample with randomly distributed curcumin nanoparticles; (e) TEM micrograph of the EHOPG sample; (f) TEM micrograph of the curcumin sample and (g) TEM image of the curcumin-EHOPG sample and (h) top view magnified AFM image of pores over the surface of the EHOPG.

$200 \mathrm{~nm}$ and it has spherical shape. The identical curcumin nanoparticles we can observe on TEM micrograph-Fig. 1f. In Fig. 1c, top view AFM image of the curcumin-EHOPG sample is presented. Average lateral dimension of curcumin functionalized EHOPG sheets is $5 \mu \mathrm{m}$ whereas average height size is about $1 \mathrm{~nm}$ (inset of Fig. 1c). In Fig. 1d we can notice randomly distributed curcumin nanoparticles over the EHOPG surface. Curcumin nanoparticles are attached to the EHOPG surface on the unevenness (defect sites) of this surface. In Fig. $1 \mathrm{~g}$ and $\mathrm{h}$ we can observe pores with average diameter of $150 \mathrm{~nm}$. Functionalization of the EHOPG sheets with curcumin nanoparticles contributes to increase of pore diameters incorporated in the EHOPG sheets by APS.

Average values of rms of the EHOPG and curcumin-EHOPG samples are determined by Gwyddion software ${ }^{42}$ and obtained values are 0.393 and $1.206 \mathrm{~nm}$, respectively. After functionalization with curcumin rms of the curcumin-EHOPG sample is increased three times.

\subsection{Zeta potential measurements of the EHOPG, curcumin} and curcumin-EHOPG

Zeta potential is an important factor for characterizing the stability of colloids. We have measured zeta potentials of the EHOPG, curcumin and curcumin-EHOPG colloids. Values of zeta potentials of all samples are presented in Table 1. The $\mathrm{pH}$ values of aqueous colloids were tuned to 7 and 14 . The measured values of zeta potentials indicate that colloids are stabilized electrostatically and have shown good stability. There was no sign of agglomeration of graphene sheets after more than two months. Colloids of all samples are negatively charged and stabilized by electrostatic forces. Values of zeta potentials are $\mathrm{pH}$ dependent which is consistent with the fact that the ionization of carboxylic acid groups is strongly related to $\mathrm{pH}$.

By increasing $\mathrm{pH}$ of all colloids, zeta potentials are increased and their stabilities are much better, except for the curcuminEHOPG colloids. For these colloids values of zeta potential have not changed. In the acid environment all colloids become unstable.

\subsection{UV-vis and FTIR measurements of EHOPG, curcumin and curcumin-EHOPG}

Fig. 2a presents UV-vis spectra of the EHOPG sample-curve 1, the curcumin sample-curve 2 and the curcumin-EHOPG sample-curve 3. As for the EHOPG sample we can notice one broad absorption peak at $270 \mathrm{~nm}$ which is assigned to $\pi-\pi$ transition of C-C bonds. ${ }^{50}$ The curcumin spectrum exhibits two absorption bands: the first at $235 \mathrm{~nm}$ which is assigned to $\pi-\pi$ transition of C-C bonds; and the second at $422 \mathrm{~nm}$ which is corresponded to $\mathrm{n}-\pi^{*}$ transition of $\mathrm{C}=\mathrm{O}$ bonds. ${ }^{19}$ As for the curcumin-EHOPG sample, one absorption peak at $270 \mathrm{~nm}$ which corresponds to $\pi-\pi$ transition of $\mathrm{C}-\mathrm{C}$ bonds is detected. The second shoulder at $472 \mathrm{~nm}$ corresponds to $\mathrm{n}-\pi^{*}$ transition of $\mathrm{C}=\mathrm{O}$ bonds.

The FTIR spectra of the curcumin, EHOPG and curcuminEHOPG particles are presented in Fig. 2b. The FTIR spectra of all samples show one wide peak at $3400 \mathrm{~cm}^{-1}$ which stem from $\mathrm{O}-\mathrm{H}$ vibrations and two small peaks at 2830 and $2920 \mathrm{~cm}^{-1}$ which stem from $\mathrm{C}-\mathrm{H}$ stretching vibrations.

As for EHOPG sample (curve 1), the peak at $2170 \mathrm{~cm}^{-1}$ indicates skeletal vibrations from un-oxidized graphitic domains. The peak at $1720 \mathrm{~cm}^{-1}$ indicate the presence of $\mathrm{C}=\mathrm{O}$ stretching vibrations while the peaks at 1420 and $1050 \mathrm{~cm}^{-1}$ stem from C-O stretching vibrations. The peak at $1640 \mathrm{~cm}^{-1}$

Table 1 The values of zeta potential of the curcumin, EHOPG and curcumin-EHOPG samples

\begin{tabular}{lll}
\hline & \multicolumn{2}{l}{ Zeta potential $(\mathrm{mV})$} \\
\cline { 2 - 3 } Sample & $\mathrm{pH} \mathrm{7}$ & $\mathrm{pH} \mathrm{14}$ \\
\hline Curcumin & -45.48 & -56.0 \\
EHOPG & -30.2 & -41.7 \\
Curcumin-EHOPG & -41.9 & -41.6
\end{tabular}



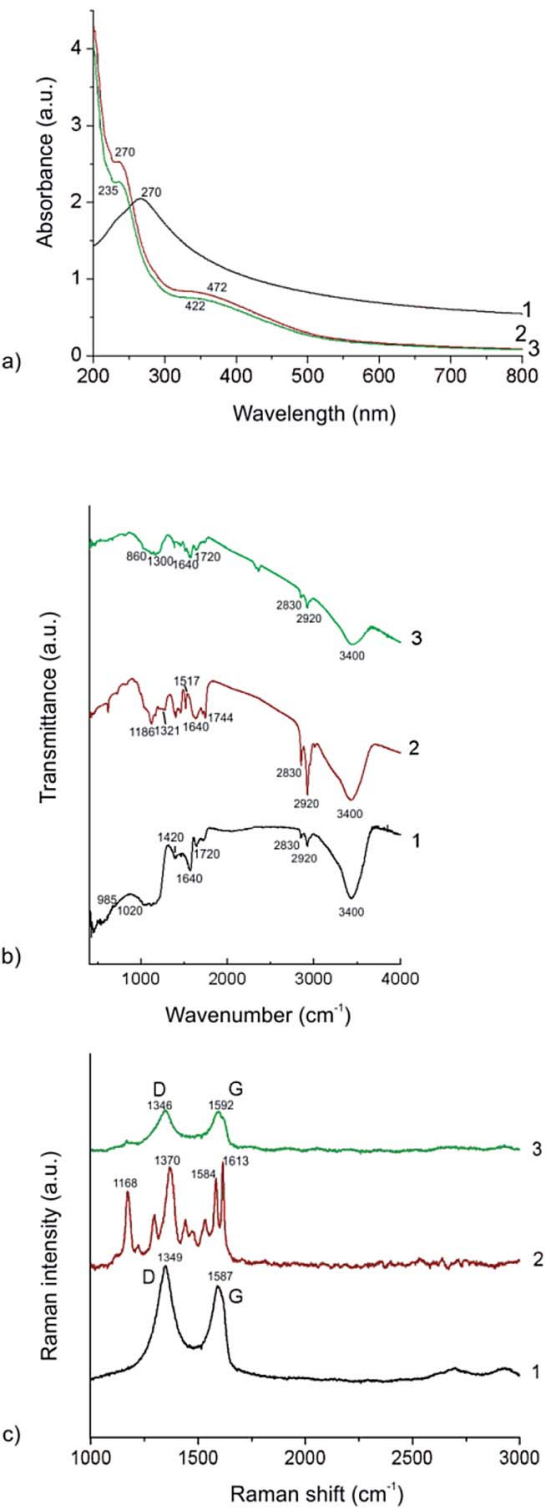

Fig. 2 (a) UV-vis spectra of the EHOPG sample-curve 1; the curcumin sample-curve 2; the curcumin-EHOPG sample; (b) FTIR spectra of the EHOPG sample-curve 1; the curcumin sample-curve 2; curcuminEHOPG sample-curve 3; (c) Raman spectra of the EHOPG-curve 1; the curcumin sample-curve 2; curcumin-EHOPG sample-curve 3.

stem from mixing of $\mathrm{C}=\mathrm{C}$ and $\mathrm{C}=\mathrm{O}$ vibrations. The peaks at 985 and $1020 \mathrm{~cm}^{-1}$ stem from intercalated sulfate ions. ${ }^{41}$

As for the curcumin sample (curve 2), we can identify several peaks which stemming from carbonyl groups $(1744,1714,1640$, $1517 \mathrm{~cm}^{-1}$ ) whereas the band at $1321-1186 \mathrm{~cm}^{-1}$ stem from $\mathrm{CH}_{3}$ vibrations. ${ }^{19}$ The peak at $1120 \mathrm{~cm}^{-1}$ stem from $\mathrm{O}-\mathrm{CH}_{3}$ vibrations. The peaks at 2830 and $2920 \mathrm{~cm}^{-1}$ which stemming from $\mathrm{C}-\mathrm{H}$ stretching vibrations appears in the curcumin FTIR spectrum due to the presence of ethanol.

As for the curcumin-EHOPG sample (curve 3), there are overlappings of some bands between 860 and $1780 \mathrm{~cm}^{-1}$. Band at $860-1300 \mathrm{~cm}^{-1}$ stem from mixing vibrations of sulfate ions and $\mathrm{CH}_{3}$ and $\mathrm{O}-\mathrm{CH}_{3}$ vibrations whereas the peaks at 1640 and $1720 \mathrm{~cm}^{-1}$ stem from $\mathrm{C}=\mathrm{O}$ vibrations.

\subsection{Raman spectroscopy of EHOPG, curcumin, curcumin-} EHOPG

Raman spectroscopy is a very powerful tool for chemical analysis of different materials especially carbon nanomaterials. ${ }^{51}$ As for graphene there are three characteristic features: $\mathrm{G}$ band at $1580 \mathrm{~cm}^{-1}$ which is assigned to the $E_{2 \mathrm{~g}}$ phonon of $\mathrm{sp}^{2}$ bonds of carbon atoms, the D band at $1350 \mathrm{~cm}^{-1}$ as a breathing mode of $k$-point phonons of $A_{1 \mathrm{~g}}$ symmetry, which is attributed to local defects and disorders particularly the defects located at the edges of graphene and $2 \mathrm{D}$ band at $2700 \mathrm{~cm}^{-1}$ which represents the second harmonic of the $\mathrm{D}$ band. ${ }^{52}$

In Fig. 2c, Raman spectra of the EHOPG (curve 1), curcumin (curve 2) and curcumin-EHOPG (curve 3) are presented. Raman spectra of all samples are normalized to G band (the EHOPG and curcumin-EHOPG) and to the highest peak intensity of curcumin sample. Raman spectra of the EHOPG and curcuminEHOPG are fitted with 2 Lorentzian peaks and the fitting results are given in Table 2.

Based on data presented in Table 2 we can conclude the following: the $\mathrm{G}$ band of the EHOPG is up-shifted $6.6 \mathrm{~cm}^{-1}$ compared to the starting material (HOPG-1580 $\mathrm{cm}^{-1}$ ) due to intercalation of sulfate ion during the exfoliation process. After functionalization of the EHOPG with curcumin G band is upshifted $5.3 \mathrm{~cm}^{-1}$ additionally. This up-shift indicates that there is a charge transfer between the EHOPG and curcumin and EHOPG gives their electrons to curcumin. The ratio between carbon atoms with $\mathrm{sp}^{2}$ and $\mathrm{sp}^{3}$ hybridization in the graphitic lattice is an indication of the degree of oxidation or a covalent functionalization reaction. This ratio is estimated using Raman spectroscopy as the $I_{\mathrm{D}} / I_{\mathrm{G}}$ ratio, where $I_{\mathrm{D}}$ and $I_{\mathrm{G}}$ are the intensities of the peaks at $\sim 1350$ and $1580 \mathrm{~cm}^{-1} .{ }^{53}$ The $I_{\mathrm{D}} / I_{\mathrm{G}}$ ratio has been changed from 1.03 (EHOPG) to 1.06 (curcumin-EHOPG). This difference is very small (about $3 \%$ ). But it can indicate covalent functionalization of EHOPG by curcumin. This result is in a strong correlation with zeta potential measurements which have shown long-term stability of these colloids.

\subsection{Electron paramagnetic resonance spectroscopy of EHOPG, curcumin and curcumin-EHOPG}

EPR spectroscopy was used to determinate the ability of the EHOPG, curcumin and curcumin-EHOPG samples to produce different ROS: singlet oxygen $\left({ }^{1} \mathrm{O}_{2}\right)$, hydroxyl $\left(\mathrm{HO}^{*}\right)$ and superoxide radical $\left(\mathrm{O}_{2}^{-\cdot}\right)$.

The singlet oxygen production of studied dispersions was analyzed using a selective trap agent TEMP (Fig. 3). The technique is based on reaction between TEMP and singlet oxygen which leads to formation a stable, EPR active compound,

Table 2 The position of D and G bands as well as FWHM of the EHOPG and curcumin-EHOPG samples

\begin{tabular}{llll}
\hline Sample & D band $\left(\mathrm{cm}^{-1}\right)$ & G band $\left(\mathrm{cm}^{-1}\right)$ & FWHM $\left(\mathrm{cm}^{-1}\right)$ \\
\hline EHOPG & 1349.4 & 1586.6 & 61.65 \\
Curcumin-EHOPG & 1346.1 & 1591.9 & 62.01
\end{tabular}




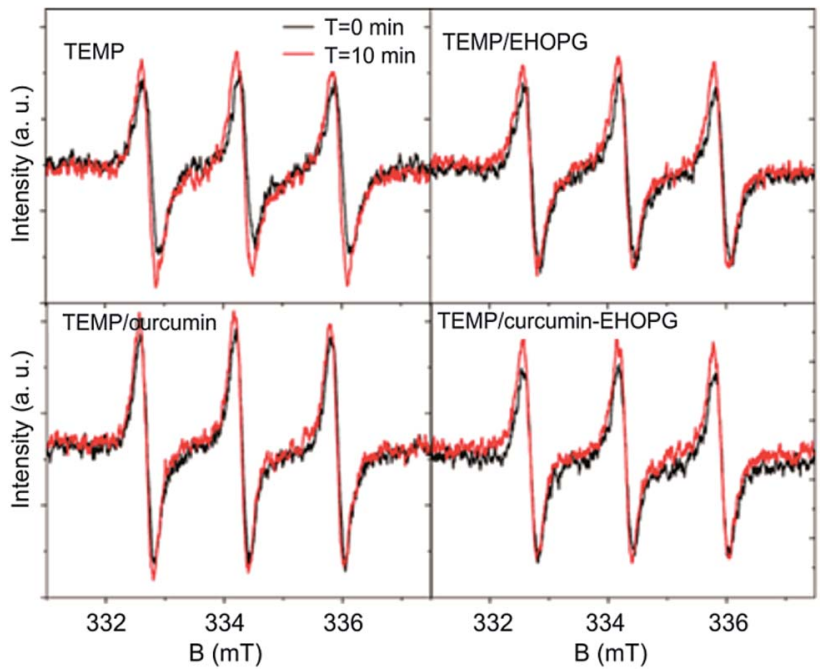

Fig. 3 EPR spectra of TEMP solution in dark conditions ( $T=0$ minutes, black line) and after 10 minutes of UV-light exposure $(T=10$, red curve), TEMP mixed with the EHOPG, curcumin and curcuminEHOPG at $T=0$ and 10 minutes.

2,2,6,6-tetramethylpiperidine-1-oxyl (TEMPO). The singlet oxygen production in sample was measured before and after photo-excitation.

The control measurements, TEMP solution before and after light exposure showed a small TEMPO formation. After adding samples, there are no significant changes in the intensity of signal characteristic for TEMPO. Even after 10 minutes of light exposure, there is no intensity increase of TEMPO signal.

As for production of hydroxyl and superoxide radicals, we used DMPO as a spin trap. First, we measured DMPO with and without light exposure and noticed that there is no significant EPR signals. But with Fenton reaction, very strong, EPR signals can be observed.

EPR measurements of samples mixed with DMPO did not show any differences compared to EPR spectra of clean DMPOFig. 4. Even after light exposure, the production of hydroxyl and superoxide radicals cannot be detected. These results suggest that analyzed samples cannot produces oxygen contacting radical species, under studied conditions.

These results suggest that investigated samples do not produce singlet oxygen. Furthermore, prolonged UV photoexcitation did not caused changes in singlet oxygen production.

There are some reports concerning singlet oxygen and superoxide production of curcumin. ${ }^{54,55}$ Curcumin produced singlet oxygen upon irradiation (wavelength higher than 400 $\mathrm{nm}$ ) in toluene or acetonitrile; in acetonitrile curcumin also quenched ${ }^{1} \mathrm{O}_{2}$. In such case the degradation of curcumin after photoexcitation must proceed though the triplet excited state of curcumin..$^{56}$ Photo-physical studies reported the lifetime of triplet excited state of curcumin to be in microseconds, suggesting that the degradation may proceed very fast and compete with singlet oxygen formation. Our EPR measurements of singlet oxygen and superoxide have shown that the EHOPG, curcumin and curcumin-EHOPG samples do not produce ROS under any conditions.

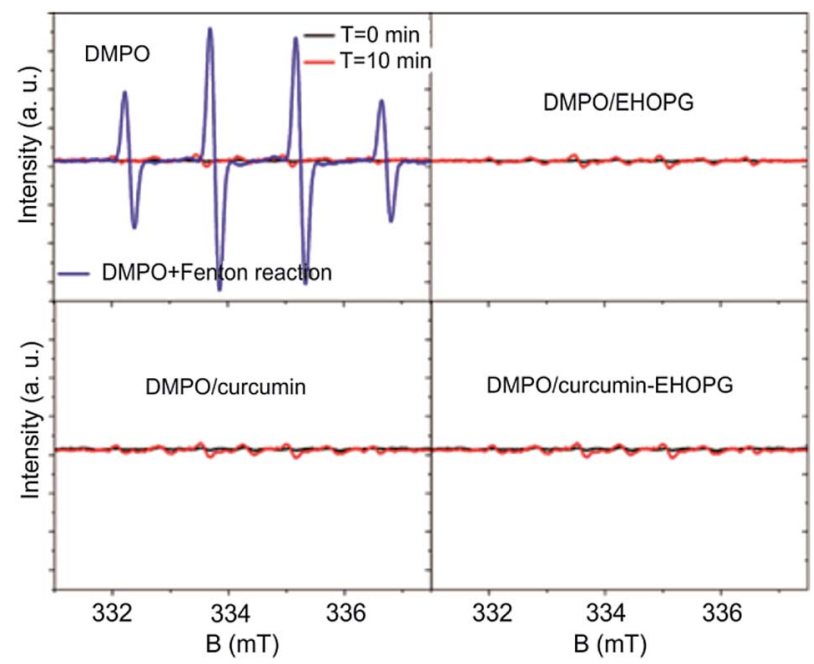

Fig. 4 EPR spectra of DMPO solution in dark conditions $(T=0$, black line), after 10 minutes of UV-light exposure ( $T=10$, red curve), with Fenton reaction (blue curve), DMPO mixed with EHOPG, curcumin and curcumin-EHOPG at $T=0$ and 10 minutes.

\subsection{Antibacterial activity of EHOPG, curcumin and curcumin-EHOPG}

The effect of the EHOPG, curcumin, and curcumin-EHOPG on the growth of $E$. coli and $S$. aureus was investigated. The growth curves of tested bacteria treated with different concentrations of EHOPG $\left(0.125-0.5 \mathrm{mg} \mathrm{mL}^{-1}\right)$, curcumin $\left(0.125-2 \mathrm{mg} \mathrm{mL}^{-1}\right)$ and curcumin-EHOPG $\left(0.125-1 \mathrm{mg} \mathrm{mL}^{-1}\right)$, evaluated by measuring of $\mathrm{OD}_{630}$ are shown in Fig. $5 \mathrm{a}-\mathrm{f}$. Due to the presence of the material that affects the interpretation of the data, the optical density of the bacteria cultures was corrected for $\mathrm{OD}_{630}$ of sterile media with the EHOPG, curcumin or curcumin-EHOPG at each point on the curve. The material influenced the results by changing the colour of the medium or by its own precipitation by the end of the incubation.

The results of measuring of $\mathrm{OD}_{630}$ showed that E. coli cells were able to grow in the presence of the applied concentrations of the samples (Fig. 5a-c). At the concentrations of curcumin ranging from 0.5 to $2 \mathrm{mg} \mathrm{mL} \mathrm{mL}^{-1}$ lower $\mathrm{OD}_{630}$ values were detected compared to control, the same results were obtained with $0.5 \mathrm{mg} \mathrm{mL}^{-1}$ of the EHOPG and with 0.5 and $1 \mathrm{mg} \mathrm{mL}^{-1}$ of the curcumin-EHOPG. Lower concentrations of samples (curcumin, EHOPG and curcumin-EHOPG) did not influence the growth of $E$. coli which was able to reach the same final $\mathrm{OD}_{630}$ as untreated cells.

In the case of $S$. aureus treated with the EHOPG (Fig. 5d), a bacterial growth phase was not detected when the concentration of $0.5 \mathrm{mg} \mathrm{mL} \mathrm{m}^{-1}$ was used. The concentration $0.25 \mathrm{mg}$ $\mathrm{mL}^{-1}$ of the EHOPG induced an extended lag phase and the attained $\mathrm{OD}_{630}$ value amounted to half of the maximum. $S$. aureus cells exposed to $0.125 \mathrm{mg} \mathrm{mL}^{-1}$ of EHOPG were able to grow undisturbed. When the concentrations of curcumin were in the range of 0.5 to $2 \mathrm{mg} \mathrm{mL}^{-1}$, no growth of $S$. aureus could be detected within $24 \mathrm{~h}$ (Fig. 5e). The treatment with $0.25 \mathrm{mg} \mathrm{mL}^{-1}$ of curcumin resulted in a lower final $\mathrm{OD}_{630}$ value, while at 

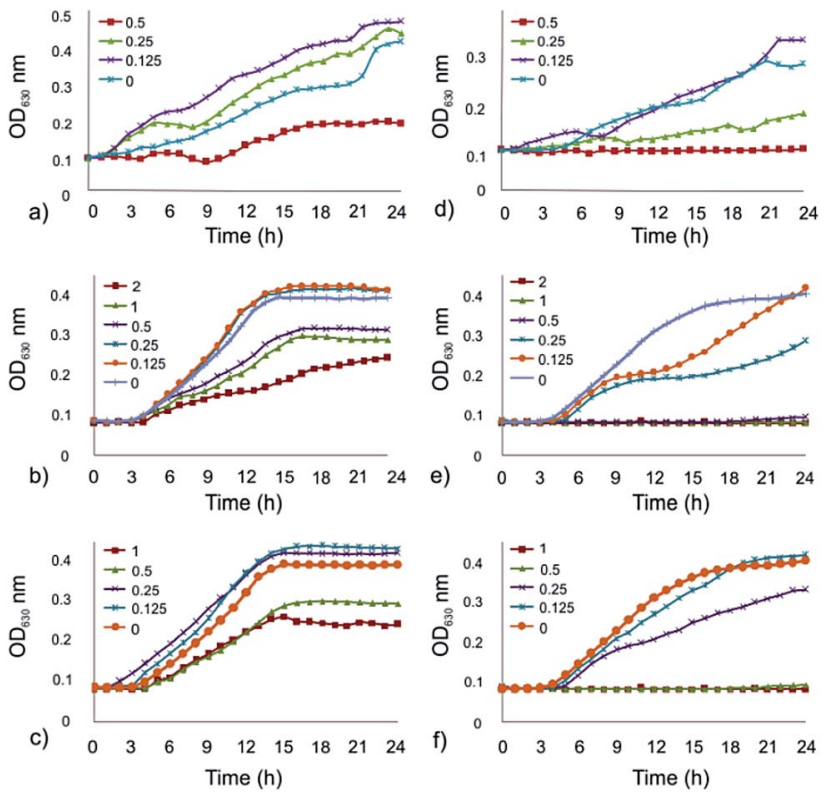

Fig. 5 Optical density of test culture in the media supplemented with: (a) EHOPG at the concentration $0-0.5 \mathrm{mg} \mathrm{mL}^{-1}-E$. coli, (b) curcumin at the concentration $0-2 \mathrm{mg} \mathrm{mL}^{-1}-E$. coli, (c) curcumin-EHOPG at the concentration 0-1 mg mL ${ }^{-1}-E$. coli, (d) EHOPG at the concentration $0-0.5 \mathrm{mg} \mathrm{mL}^{-1}-S$. aureus, (e) curcumin at the concentration 0-2 $\mathrm{mg} \mathrm{mL}^{-1}-\mathrm{S}$. aureus, (f) curcumin-EHOPG at the concentration $0-2 \mathrm{mg} \mathrm{mL}^{-1}-S$. aureus.

$0.125 \mathrm{mg} \mathrm{mL} \mathrm{m}^{-1} \mathrm{~S}$. aureus cells were able to grow undisturbed. Similar results were obtained when $S$. aureus cells were treated with the curcumin-EHOPG (Fig. 5f).

The concentrations of 0.5 and $1 \mathrm{mg} \mathrm{mL}^{-1}$ acted inhibitory, while at $0.25 \mathrm{mg} \mathrm{mL}^{-1}$ of the curcumin-EHOPG lower final $\mathrm{OD}_{630}$ value was observed. At the lowest tested concentration $(0.125 \mathrm{mg}$ $\mathrm{mL}^{-1}$ ) of curcumin-EHOPG growth curve run parallel with that of the positive control and reached the same final $\mathrm{OD}_{630}$.
Since the total number of bacteria, including live and dead ones is assayed by $\mathrm{OD}_{630}$, a decline phase could not be detected on the growth curves. Additionally, considering the difficulty in interpreting results due to precipitation of material, an alternative viable count assay was utilized. As shown in Table 3, E. coli cells were able to grow in the presence of EHOPG, curcumin and curcumin-EHOPG at the concentrations of $0.5 \mathrm{mg} \mathrm{mL} \mathrm{m}^{-1}$, $2 \mathrm{mg} \mathrm{mL}{ }^{-1}$ and $1 \mathrm{mg} \mathrm{mL}^{-1}$, respectively but the decline phase started earlier compared with the control.

Treatment of $S$. aureus with $2 \mathrm{mg} \mathrm{mL}^{-1}$ of curcumin resulted in approximately $1 \log _{10}$ reduction during the first $6 \mathrm{~h}$ and after $9 \mathrm{~h}$ bactericidal effect was established. The concentration of $1 \mathrm{mg} \mathrm{mL} \mathrm{m}^{-1}$ of curcumin and curcumin-EHOPG was noted as minimum inhibitory concentration (MIC) since a significant decrease $(>90 \%)$ in inoculum viability after $24 \mathrm{~h}$ of incubation was observed. At the concentration of $0.5 \mathrm{mg} \mathrm{mL}^{-1}$ of curcumin, EHOPG and curcumin-EHOPG bacteriostatic activity was observed and after $24 \mathrm{~h}$ there was no significant difference between samples $(\alpha \leq 0.05)$.

\subsection{Morphology of bacteria strains}

Fig. 6a-d present surface morphology of ECC, ECEHOPG, ECCU, ECCUEHOPG samples whereas Fig. 6e-h present the corresponding EDS spectra of these samples. As we can observe from Fig. $6 \mathrm{a}$ average lengths of $E$. coli strains are $2 \mu \mathrm{m}$. In Fig. $6 \mathrm{~b}$ we could detect very small visual damages on bacteria membrane after interaction with the EHOPG. Similar changes can be observed in Fig. $6 \mathrm{c}$ and d for interactions of $E$. coli with the curcumin and curcumin-EHOPG.

EDS distribution of elements on untreated bacteria membrane have shown homogeneous distribution of $\mathrm{C}, \mathrm{O}, \mathrm{Na}$ and $\mathrm{P}$ on bacteria membrane-Fig. 6e. After interaction with the EHOPG, curcumin, curcumin-EHOPG, distributions of certain elements have been changed. The EDS qualitative analysis of the ECC, ECEHOPG, ECCU and ECCUEHOPG samples

Table 3 The antibacterial activity of the EHOPG, curcumin and curcumin-EHOPG expressed as $\log _{10} \mathrm{CFU}_{\mathrm{mL}}{ }^{-1}$ determined by the broth macrodilution method $^{a}$

\begin{tabular}{|c|c|c|c|c|c|}
\hline \multicolumn{6}{|l|}{${ }^{b} \log _{10} \mathrm{CFU} \mathrm{mL} \mathrm{L}^{-1}$} \\
\hline Bacterial strain & $0 \mathrm{~h}$ & $3 \mathrm{~h}$ & $6 \mathrm{~h}$ & $9 \mathrm{~h}$ & $24 \mathrm{~h}$ \\
\hline ECC & $5.3 \pm 0.3^{\mathrm{a} c}$ & $7.0 \pm 0.5^{\mathrm{a}}$ & $8.6 \pm 0.3^{\mathrm{a}}$ & $8.7 \pm 0.3^{\mathrm{a}}$ & $9.9 \pm 0.6^{\mathrm{a}}$ \\
\hline $\mathrm{U}\left(2 \mathrm{mg} \mathrm{mL}^{-1}\right)$ & $5.2 \pm 0.2^{\mathrm{a}}$ & $6.4 \pm 0.2^{\mathrm{a}}$ & $7.7 \pm 0.3^{\mathrm{b}}$ & $8.2 \pm 0.1^{\mathrm{ab}}$ & $7.3 \pm 0.2^{\mathrm{b}}$ \\
\hline ECEHOPG $\left(0.5 \mathrm{mg} \mathrm{mL}^{-1}\right)$ & $5.4 \pm 0.3^{\mathrm{a}}$ & $6.3 \pm 0.1^{\mathrm{a}}$ & $7.7 \pm 0.2^{\mathrm{b}}$ & $8.0 \pm 0.2^{\mathrm{b}}$ & $7.2 \pm 0.2^{\mathrm{b}}$ \\
\hline ECCUEHOPG $\left(1 \mathrm{mg} \mathrm{mL}^{-1}\right)$ & $5.3 \pm 0.2^{\mathrm{a}}$ & $6.3 \pm 0.1^{\mathrm{a}}$ & $7.8 \pm 0.2^{\mathrm{b}}$ & $8.5 \pm 0.2^{\mathrm{ab}}$ & $7.5 \pm 0.3^{\mathrm{b}}$ \\
\hline SAC & $5.1 \pm 0.2^{\mathrm{a}}$ & $6.5 \pm 0.2^{\mathrm{a}}$ & $7.2 \pm 0.4^{\mathrm{a}}$ & $8.5 \pm 0.4^{\mathrm{a}}$ & $8.8 \pm 0.3^{\mathrm{a}}$ \\
\hline SACU $\left(2 \mathrm{mg} \mathrm{mL}^{-1}\right)$ & $4.8 \pm 0.3^{\mathrm{a}}$ & $4.3 \pm 0.1^{\mathrm{c}}$ & $2.9 \pm 0.2^{\mathrm{e}}$ & $0.0 \pm 0.0^{g}$ & $0.0 \pm 0.0^{\mathrm{e}}$ \\
\hline SACU $\left(1 \mathrm{mg} \mathrm{mL}^{-1}\right)$ & $5.0 \pm 0.1^{\mathrm{a}}$ & $4.5 \pm 0.2^{\mathrm{c}}$ & $4.4 \pm 0.1^{\mathrm{d}}$ & $4.0 \pm 0.1^{\mathrm{f}}$ & $3.8 \pm 0.2^{\mathrm{d}}$ \\
\hline SACU $\left(0.5 \mathrm{mg} \mathrm{mL}^{-1}\right)$ & $5.0 \pm 0.1^{\mathrm{a}}$ & $4.5 \pm 0.2^{\mathrm{c}}$ & $5.3 \pm 0.2^{\mathrm{c}}$ & $5.6 \pm 0.2^{\mathrm{d}}$ & $6.1 \pm 0.3^{c}$ \\
\hline SACU $\left(0.25 \mathrm{mg} \mathrm{mL}^{-1}\right)$ & $5.1 \pm 0.2^{\mathrm{a}}$ & $5.2 \pm 0.2^{\mathrm{b}}$ & $6.1 \pm 0.1^{\mathrm{b}}$ & $6.5 \pm 0.3^{c}$ & $8.0 \pm 0.2^{\mathrm{b}}$ \\
\hline SAEHOPG $\left(0.5 \mathrm{mg} \mathrm{mL}^{-1}\right)$ & $4.9 \pm 0.2^{\mathrm{a}}$ & $5.4 \pm 0.2^{\mathrm{b}}$ & $5.2 \pm 0.2^{\mathrm{c}}$ & $5.4 \pm 0.2^{\mathrm{d}}$ & $5.7 \pm 0.3^{\mathrm{c}}$ \\
\hline SACUEHOPG $\left(1 \mathrm{mg} \mathrm{mL}^{-1}\right)$ & $5.2 \pm 0.3^{\mathrm{a}}$ & $4.4 \pm 0.1^{\mathrm{c}}$ & $4.8 \pm 0.2^{\mathrm{cd}}$ & $4.7 \pm 0.2^{\mathrm{e}}$ & $4.1 \pm 0.1^{\mathrm{d}}$ \\
\hline SACUEHOPG $\left(0.5 \mathrm{mg} \mathrm{mL}^{-1}\right)$ & $4.9 \pm 0.2^{\mathrm{a}}$ & $5.0 \pm 0.1^{b}$ & $5.3 \pm 0.2^{\mathrm{c}}$ & $6.0 \pm 0.2^{\mathrm{cd}}$ & $6.0 \pm 0.2^{\mathrm{c}}$ \\
\hline SACUEHOPG $\left(0.25 \mathrm{mg} \mathrm{mL}^{-1}\right)$ & $5.0 \pm 0.1^{\mathrm{a}}$ & $5.1 \pm 0.2^{\mathrm{b}}$ & $6.4 \pm 0.4^{\mathrm{b}}$ & $7.5 \pm 0.3^{\mathrm{b}}$ & $8.8 \pm 0.4^{\mathrm{a}}$ \\
\hline
\end{tabular}

${ }^{a} \mathrm{C}$ - control, $\log _{10} \mathrm{CFU} \mathrm{mL}^{-1}$ without EHOPG, curcumin and curcumin-EHOPG. ${ }^{b}$ Data are expressed as mean \pm standard deviation $(n=3)$. ${ }^{c}$ Within the same column, means followed by different letters are significantly different at $\alpha \leq 0.05$ (ANOVA, Tukey's HSD test). 


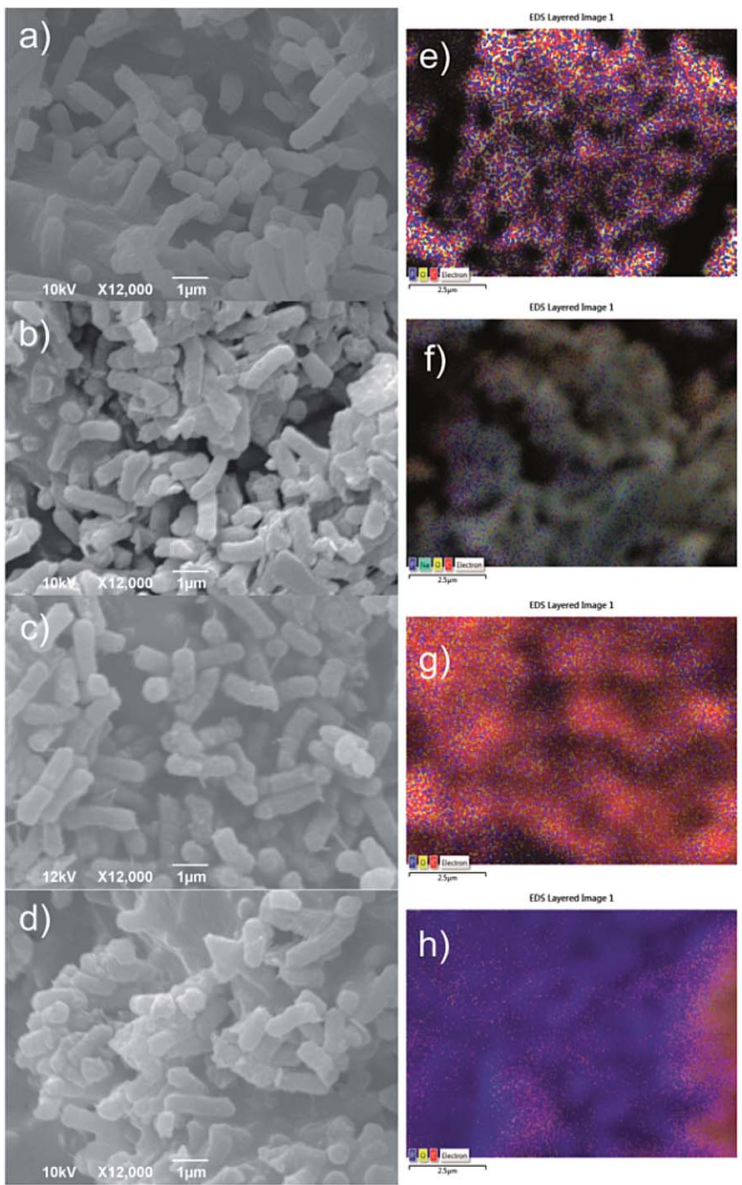

Fig. 6 SEM micrographs of (a) ECC, (b) ECEHOPG, (c) ECCU, (d) ECCUEHOPG samples and corresponding EDS distribution of detected elements over the scanned area of the sample $(e-h)$.

presented in Table 4 have shown that the content of $\mathrm{C}$ has changed very low, content of $\mathrm{O}$ is 3 and 5 times higher for the ECEHOPG and ECCU, respectively. For the ECCUEHOPG sample the content of $\mathrm{O}$ decreased slightly whereas the content of $\mathrm{P}$ is 2.3 times higher compared to the ECC. In Fig. $6 \mathrm{f}$ we can observe non-uniform distribution of $\mathrm{P}$, whereas Fig. $6 \mathrm{~g}$ presents uniform distributions of $\mathrm{C}$ and P. Fig. $6 \mathrm{~h}$ indicates uniform distribution of $\mathrm{P}$. We can observe in this figure that $\mathrm{P}$ could be detected all over investigated surface even in areas that bacteria

Table 4 EDS distribution of detected elements over the scanned area of the sample in $w t \%$

\begin{tabular}{llllrll}
\hline Sample & $\mathrm{C}$ & $\mathrm{P}$ & $\mathrm{Na}$ & $\mathrm{O}$ & $\mathrm{P}: \mathrm{C}$ & $\mathrm{O}: \mathrm{C}$ \\
\hline ECC & 97.11 & 0.63 & - & 2.25 & 0.006 & 0.023 \\
ECEHOPG & 92.41 & - & 1.30 & 6.29 & - & 0.068 \\
ECCU & 88.12 & 0.83 & - & 11.05 & 0.009 & 0.125 \\
ECCUEHOPG & 96.54 & 1.47 & 0.15 & 1.84 & 0.015 & 0.019 \\
SAC & 82.45 & 2.88 & 2.47 & 12.20 & 0.035 & 0.148 \\
SAEHOPG & 90.37 & 1.79 & 2.27 & 5.58 & 0.020 & 0.062 \\
SACU & 94.42 & - & 0.12 & 5.46 & - & 0.058 \\
SACUEHOPG & 94.38 & - & 0.07 & 5.55 & - & 0.059
\end{tabular}

strains could not be noticed. This fact may indicate bacterial membrane damage.

Fig. 7a-d present SEM micrographs of surface morphology of SAC, SAEHOPG, SACU and SACUEHOPG samples whereas Fig. 7e-h present corresponding EDS distributions of elements detected on bacteria membrane. As can be seen from Fig. 7a average diameter of $S$. aureus is $500 \mathrm{~nm}$. In Fig. $7 \mathrm{~b}$ one can observe very small changes on bacteria membranes after interaction with the EHOPG.

In Fig. 7c and d we cannot observe any bacteria strains. EDS distribution of detected elements are homogeneous only on untreated $S$. aureus (Fig. 7e) whereas there are some changes in distribution of elements of treated bacteria strains (Fig. $7 \mathrm{f}-\mathrm{h}$ ). Table 4 presents changes of contents of detected elements on bacteria membrane. The content of $\mathrm{C}$ increased after interaction of $S$. aureus with all samples whereas the content of $\mathrm{O}$ decreased almost twice after interaction of $S$. aureus with all samples. $\mathrm{P}$ could not be detected over the scanned area on the SACU and SACUEHOPG. Complete absence of $\mathrm{P}$ on bacteria membrane after interaction with the curcumin and curcuminEHOPG may indicate membrane damage.

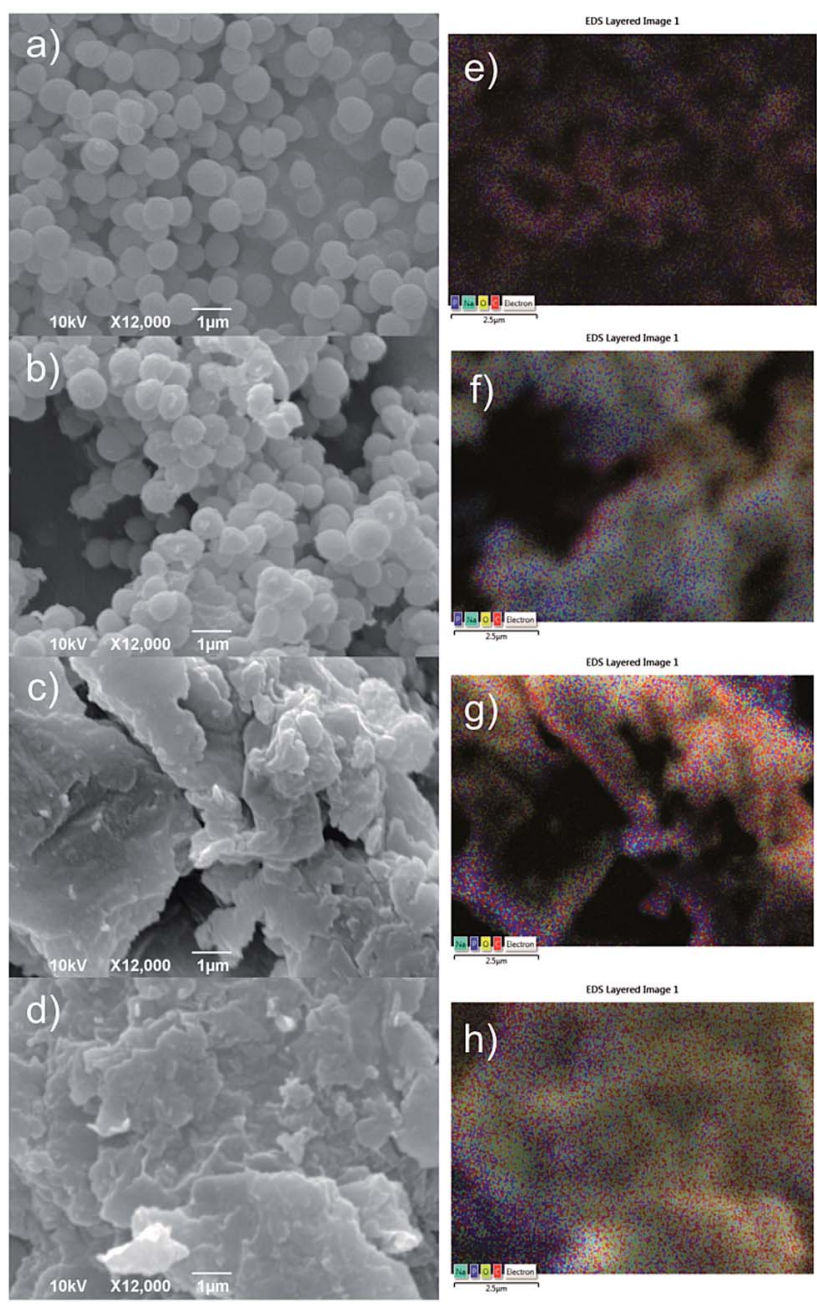

Fig. 7 SEM micrographs of (a) SAC, (b) SAEHOPG, (c) SACU, (d) SACUEHOPG samples and corresponding EDS distribution of detected elements over the scanned area of the sample $(e-h)$. 


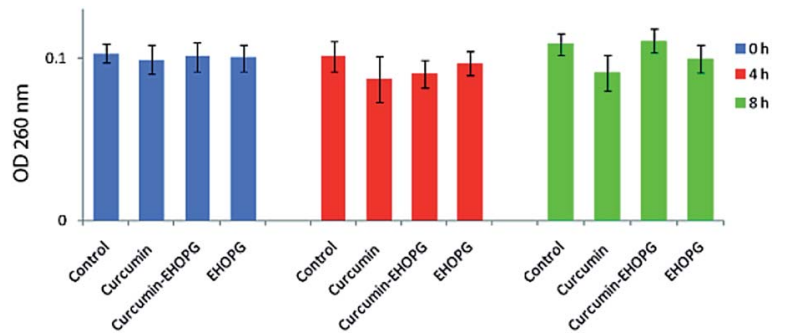

Fig. 8 Presence of $260 \mathrm{~nm}$-absorbing material in the filtrates of $S$. aureus after treatment with curcumin, curcumin-EHOPG and EHOPG at 4 and $8 \mathrm{~h}$, compared to $S$. aureus control suspension. The mean \pm SD for three replicates are illustrated.

\subsection{Loss of $260 \mathrm{~nm}$-absorbing material}

The presence of materials, in cell free medium, that absorb at $260 \mathrm{~nm}$ indicate that large molecules (e.g. nucleic acids) have been lost from the cell interior and that major membrane damage has occurred. The $\mathrm{OD}_{260} \mathrm{~s}$ values of the filtrates from $S$. aureus control suspensions remained approximately the same after $4 \mathrm{~h}$ as well as after $8 \mathrm{~h}$. The $\mathrm{OD}_{260} \mathrm{~S}$ of the filtrates from $S$. aureus suspensions treated with $1 \mathrm{mg} \mathrm{mL} \mathrm{m}^{-1}, 0.5 \mathrm{mg} \mathrm{mL} \mathrm{m}^{-1}$ and $1 \mathrm{mg} \mathrm{mL} \mathrm{m}^{-1}$ of curcumin, EHOPG and curcumin-EHOPG also remained almost the same during the whole assay period (Fig. 8).

\section{Discussion}

Different parameters such as lateral dimension of graphene sheets, surface roughness, concentration, functionalization, dispersibility, chemical composition, hydrophobicity affect significantly the antibacterial activity of graphene and curcumin-graphene nanomesh hybrids. ${ }^{\mathbf{1 4}}$

In this study we have tried to investigate antibacterial activity of the EHOPG, curcumin and curcumin-graphene nanomesh hybrids. Our goal was to consider the effect of EHOPG functionalization by curcumin on its own antibacterial activity.

We have established that the EHOPG functionalization by curcumin contributes to the increase of lateral dimension of graphene sheets ten times, pores incorporated in the graphene sheets increase ten times as well and surface roughness of the curcumin-EHOPG sample increases three times. EPR measurements have shown that there is no production of singlet oxygen and superoxide by any of the investigated samples.

In our study the EHOPG sample showed bacteriostatic activity toward $S$. aureus in the concentration of $0.5 \mathrm{mg} \mathrm{mL}$ whereas the EHOPG sample did not induce the inhibition of $E$. coli bacterial growth in concentrations of 0.125 and $0.25 \mathrm{mg}$ $\mathrm{mL}^{-1}$. Treatment with $0.5 \mathrm{mg} \mathrm{mL}^{-1}$ concentration of the EHOPG sample resulted in a lower final $\mathrm{OD}_{630}$ value. The same minimum inhibitory concentration $\left(1 \mathrm{mg} \mathrm{mL}{ }^{-1}\right)$ was determined for curcumin and curcumin-EHOPG samples toward $S$. aureus. All tested samples had more pronounced antibacterial activity against Gram positive bacteria, $S$. aureus compared with E. coli as a representative of Gram negative strains. Schematic diagram of possible antibacterial activity of curcumin-EHOPG nanomesh hybrid is presented in Fig. 9.

An explanation for the different sensitivity among the strains could be the outer membrane surrounding the peptidoglycan (cell wall) in Gram-negative bacteria, which restricts diffusion through its lipopolysaccharide (LPS) covering. In addition, the periplasmatic space contains enzymes (such as hydrolytic and detoxifying) which are capable of breaking down foreign molecules introduced from the environment. ${ }^{38}$ On the other hand, Gram-positive bacteria lack the outer membrane and therefore are expected to be more sensitive to exposure of the curcumin, curcumin-EHOPG and EHOPG.

In previous reports by other authors are pointed out that the possible mechanism of antibacterial activity of curcumin is membrane damage. ${ }^{27}$ Furthermore, curcumin caused membrane permeabilization of both $E$. coli and $S$. aureus despite their significantly different cell wall properties. It was found also that when peptidoglycan (PGN) from $S$. aureus combined with curcumin gradually blocked the antibacterial activity of curcumin in concentration of $0-125 \mu \mathrm{g} \mathrm{mL}{ }^{-1} .^{57}$ Microscopy analysis has shown damage of the cell wall, disruption of the cytoplasmic contents, broken cell membrane and cell lysis after the treatment with curcumin. As for graphene possible mechanisms of its antibacterial activity are membrane rupture and oxidative stress.

Regarding to the obtained experimental results we have assumed that curcumin is responsible for the inhibition of bacterial growth. Furthermore, curcumin-EHOPG nanomesh hybrid has stronger antibacterial activity toward $S$. aureus compared to $E$. coli. In the case of $E$. coli bacterial strains, samples expressed similar activity. The membrane walls of most Gram-positive bacteria consist mainly of numerous layers (up to 30) of glycan, with amino acid bridges connecting each layer to other layers above and below it. Lipopolysaccharide is only attached to the outer membrane of the two layers in Gramnegative bacteria. ${ }^{57}$ Curcumin may attach to the membrane wall especially to peptidoglycan and interrupt its integrity.

Since the pronounced leakage of intracellular materials was not observed at $260 \mathrm{~nm}$, when $S$. aureus cells were treated with $1 \mathrm{mg} \mathrm{mL}{ }^{-1}, 1 \mathrm{mg} \mathrm{mL}^{-1}$ and $0.5 \mathrm{mg} \mathrm{mL}^{-1}$ of curcumin, curcumin-EHOPG and EHOPG, respectively it can be concluded that

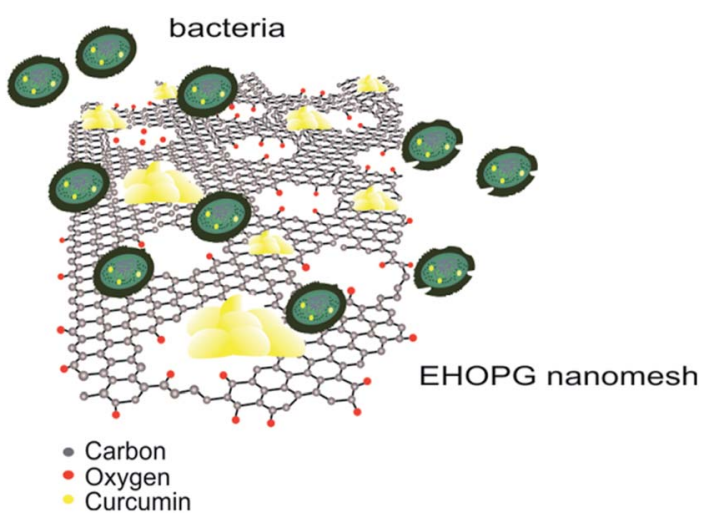

Fig. 9 Schematic diagram of possible mechanism of antibacterial activity of curcumin-EHOPG nanomesh hybrid. 
the bacterial membrane wall was the primary target on which samples acted. Moreover, previous studies reported that the leakage of intracellular materials was induced at bactericidal concentrations of phenolic compounds while on the other hand, bacteriostatic concentrations did not cause the draining out of $260 \mathrm{~nm}$ absorbing material. ${ }^{58}$ Curcumin-graphene nanomesh hybrids have stronger antibacterial activity toward $S$. aureus because their membrane walls have simpler structure that those of $E$. coli. Mitra et al. obtained similar results with curcumin loaded collagen functionalized nano graphene oxide scaffold. ${ }^{35}$

\section{Conclusions}

In this study we have used curcumin nanoparticles to functionalize exfoliated graphene sheets. Exfoliated graphene is a material with very interesting properties because it is at the same time water dispersible and conductive. It is synthesized by electrochemical exfoliation of HOPG in APS solution. Curcumin-EHOPG nanomesh hybrids were obtained by solvent exchange method. Obtained curcumin-EHOPG nanomesh hybrids have shown strong antibacterial activity especially toward $S$. aureus. As for $E$. coli bacteria strains curcumin and curcumin-EHOPG samples inhibited their growth in the same concentration. Obtained results demonstrate that curcuminEHOPG nanomesh hybrids are good candidates for antibacterial devices.

\section{Conflicts of interest}

There are no conflicts of interest to declare.

\section{Acknowledgements}

This research was supported by the Ministry of Education, Science and Technological Development of the Republic of Serbia (project no. 172003 and III 46010) and multilateral scientific and technological cooperation in the Danube region (DS021). Research was also supported by the SASPRO Programme project $1237 / 02 / 02-b$. The research leading to these results has received funding from the People Programme (Marie Curie Actions) European Union's Seventh Framework Programme under REA grant agreement No. 609427. Research has been further co-funded by the Slovak Academy of Sciences. We are gratefully acknowledged to Mrs Marcela Kimličkova for performing zeta potential measurements.

\section{Notes and references}

1 K. S. Novoselov, A. K. Geim, S. V. Morozov, D. Jiang, Y. Zhang, S. V. Dubonos, I. V. Grigorieva and A. A. Firsov, Science, 2004, 306, 666.

2 S. Bae, H. Kim, Y. Lee, X. Xu, J. S. Park, Y. Zheng, J. Balakrishnan, T. Lei, H. R. Kim, Y. I. Song, Y. J. Kim, K. S. Kim, B. Özyilmaz, J. H. Ahn, B. H. Hong and S. Iijima, Nat. Nanotechnol., 2010, 5, 574.
3 S. Y. Yang, W. N. Lin, Y. L. Huang, H. W. Tien, J. Y. Wang, C. C. M. Ma, S. M. Li and Y. S. Wang, Carbon, 2011, 49, 793. 4 N. W. Pu, Y. Y. Peng, P. C. Wang, C. Y. Chen, J. N. Shi, Y. M. Liu, M. D. Ger and C. L. Chang, Carbon, 2014, 67, 449. 5 Q. Zhao and S. Hao, J. Compos. Mater., 2007, 41, 201.

6 A. Reina, X. Jia, J. Ho, D. Nezich, H. Son, V. Bulovic, M. S. Dresselhaus and J. Kong, Nano Lett., 2008, 9, 30.

7 S. Lee, K. Lee and Z. Zhong, Nano Lett., 2010, 10, 4702.

8 P. W. Sutter, J. I. Flege and E. A. Sutter, Nat. Mater., 2008, 7, 406.

9 K. Muthoosamy and S. Manickam, Ultrason. Sonochem., 2017, 39, 478.

10 K. Muthoosamy, R. G. Bai and S. Manickam, Curr. Drug Delivery, 2014, 11, 701.

11 K. Muthoosamy, R. G. Bai, J. B. Abubakar, S. M. Sudheer, H. N. Lim, H. S. Loh, N. M. Huang, C. H. Chia and S. Manickam, Int. J. Nanomed., 2015, 10, 1505.

12 J. Liu, C. K. Poh, D. Zhan, L. Lai, S. H. Lim, L. Wang, X. Liu, N. G. Sahoo, C. Li, Z. Shen and J. Lin, Nano Energy, 2013, 2, 377.

13 M. Zhou, J. Tang, Q. Cheng, G. Xu, P. Cui and L. Qin, Chem. Phys. Lett., 2013, 572, 61.

14 H. M. Hegab, A. ElMekawy, L. Zou, D. Mulchahy, C. P. Saint and M. Ginić Marković, Carbon, 2016, 105, 362.

15 A. M. Pinto, I. C. Gonçalves and F. D. Magalhães, Colloids Surf., B, 2013, 111, 188.

16 S. C. Smith and D. F. Rodrigues, Carbon, 2015, 91, 122.

17 J. Li, G. Wang, H. Zhu, M. Zhang, X. Zheng, Z. Di, X. Liu and X. Wang, Sci. Rep., 2014, 4, 4359.

18 L. Shi, J. Chen, L. Teng, L. Wang, G. Zhu, S. Liu, Z. Luo, X. Shi, Y. Wang and L. Ren, Small, 2016, 12, 4165.

19 Z. Marković, J. Prekodravac, D. Tošić, I. HolclajtnerAntunović, M. Milosavljević, M. Dramićanin and B. Todorović-Marković, J. Serb. Chem. Soc., 2015, 80, 63.

20 O. P. Sharma, Biochem. Pharmacol., 1976, 25, 1811.

21 T. Masuda, Y. Toi, H. Bando, T. Maekawa, Y. Takeda and H. Yamaguchi, J. Agric. Food Chem., 2002, 50, 2524.

22 K. Mehta, P. Pantazis, T. McQueen and B. Agarval, AntiCancer Drugs, 1997, 8, 471.

23 A. N. Nurfina, M. S. Reksohadiprodjo, H. Timmerman, U. Jenie, D. Sigiyanto and H. J. van der Goot, Eur. J. Med. Chem., 1997, 32, 321.

24 N. Sreejayan, M. N. A. Rao, K. I. Priyadarsini and A. T. P. Devasagayam, Int. J. Pharm., 1997, 151, 127.

25 P. Venkatesan and M. N. Rao, J. Pharm. Pharmacol., 2000, 52, 1123.

26 V. Paunović, B. Ristić, Z. Marković, B. Todorović Marković, M. Kosić, J. Prekodravac, T. Kravić Stevović, M. Micušik, Z. Spitalsky, V. Trajković and L. Harhaji Trajković, Biomed. Microdevices, 2016, 18, 37.

27 P. Tyagi, M. Singh, H. Kumari, A. Kumari and K. Mukhopadhyay, PLoS One, 2015, 10, e0121313.

28 J. Song, B. Choi, E. J. Jin, Y. Yoon and H. K. Choi, Eur. J. Clin. Microbiol. Infect. Dis., 2012, 31, 1347.

29 W. J. Betts and D. W. Wareham, BMC Microbiol., 2014, 14, 172. 
30 K. M. Moghaddam, M. Iranshahi, M. C. Yazdi and A. R. Shahverdi, Int. J. Green Pharm., 2009, 3, 141.

31 S. H. Mun, D. K. Joung, Y. S. Kim, O. H. Kang, S. B. Kim, Y. S. Seo, Y. C. Kim, D. S. Lee, D. W. Shin, K. T. Kweon and D. Y. Kwon, Phytomedicine, 2013, 20, 714.

32 A. R. Maity, A. Chakraborty, A. Mondal and N. R. Jana, Nanoscale, 2014, 6, 2752.

33 K. Muthoosamy, I. Babangida Abubakar, R. Geetha Bai, H. S. Loh and S. Manickam, Sci. Rep., 2016, 6, 32808.

34 S. Hatamie, O. Akhavan, S. K. Sadrnezhaada, M. M. Ahadian, M. M. Shirolkar and H. Q. Wang, Mater. Sci. Eng., C, 2015, 55, 482.

35 T. Mitra, P. J. Manna, S. T. K. Raja, A. Gnanamani and P. P. Kundu, RSC Adv., 2015, 5, 98653.

36 Y. J. Choi, E. Kim, J. W. Han, J. H. Kim and S. Gurunathan, Molecules, 2016, 21, 375.

37 Y. Lin, Y. Liao, Z. Chen and J. W. Connell, Mater. Res. Lett., 2017, 5, 209-234.

38 J. Bai, X. Zhong, S. Jiang, Y. Huang and X. Duan, Nat. Nanotechnol., 2010, 5, 190.

39 T. H. Han, Y. K. Huang, A. T. L. Tan, V. P. Dravid and J. Huang, J. Am. Chem. Soc., 2011, 133, 15264.

40 Z. M. Marković, D. M. Matijašević, V. B. Pavlović, S. P. Jovanović, I. D. Holclajtner-Antunović, Z. Špitalsky, M. Mičušik, M. D. Dramićanin, D. D. Milivojević, M. P. Nikšić and B. M. Todorović Marković, J. Colloid Interface Sci., 2017, 500, 30.

41 Z. M. Marković, M. D. Budimir, D. P. Kepić, I. D. HolclajtnerAntunović, M. D. Dramićanin, V. D. Spasojević, D. B. Peruško, Z. Špitalský, M. Mičušik, V. B. Pavlović and B. M. Todorović-Marković, RSC Adv., 2016, 6, 39275.

42 www.gwyddion.net, version 2.42 .

43 F. Widdel, Theory and measurement of bacterial growth, Grundpraktikum Mikrobiologie, Universität Bremen, 2007, vol. 4, p. 11.
44 A. Klančnik, S. Piskernik, B. Jeršek and S. S. Možina, J. Microbiol. Methods, 2010, 81, 121.

45 A. K. Tyagi, D. Bukvički, D. Gottardi, M. Veljić, M. E. Guerzoni, A. Malik and P. D. Marin, J. Evidence-Based Complementary Altern. Med., 2013, 2013, 382927.

46 C. F. Carson, B. J. Mee and T. V. Riley, Antimicrob. Agents Chemother., 2002, 46, 1914.

47 H. C. Schniepp, J. L. Li, M. J. McAllister, H. Sai, M. HerreraAlonso, D. H. Adamson, R. K. Prud'homme, R. Car, D. A. Saville and I. A. Aksay, J. Phys. Chem. B, 2006, 110, 8535.

48 M. J. McAllister, J. L. Li, D. H. Adamson, H. C. Schniepp, A. A. Abdala, J. Liu, M. Herrera-Alonso, D. L. Milius, R. Car, R. K. Prud'homme and I. A. Aksay, Chem. Mater., 2007, 19, 4396.

49 O. Akhavan, Carbon, 2010, 48, 509.

50 D. Li, M. B. Muller, S. Gilje, R. B. Kaner and G. Wallace, Nat. Nanotechnol., 2008, 3, 101.

51 L. M. Malard, M. A. Pimenta, G. Dresselhaus and M. S. Dresselhaus, Phys. Rep., 2009, 473, 51.

52 A. C. Ferrari, Solid State Commun., 2007, 14, 47.

53 V. Georgakilas, M. Otyepka, A. B. Bourlinos, V. Chandra, N. Kim, K. C. Kemp, P. Hobza, R. Zboril and K. S. Kim, Chem. Rev., 2012, 112, 6156.

54 C. F. Chignell, P. B. Krzysztof, J. Reszka, A. G. Motten, R. H. Sik and T. A. Dahl, Photochem. Photobiol., 1994, 59, 295. 55 H. H. Tønnesen, H. de Vries, J. Karlsen and B. V. Henegouwen, J. Pharm. Sci., 1987, 76, 371.

56 K. I. Priyadarsini, J. Photochem. Photobiol., C, 2009, 10, 81.

57 S. H. Mun, S. B. Kim, R. Kong, J. G. Choi, Y. C. Kim, D. W. Shin, O. H. Kang and D. Y. Kwon, Molecules, 2014, 19, 18283.

58 Disinfection, Sterilization and Preservation, ed. S. S. Block, Lippincott Williams \& Wilkins, Philadelphia, 2001. 